\title{
PENGARUH PROFITABILITAS, LEVERAGE, KOMPLEKSITAS OPERASI, REPUTASI KAP DAN KOMITE AUDIT TERHADAP AUDIT DELAY
}

\author{
Jahormin Simarmata dan Romi Fauzi \\ Email: jahormin.simarmata@gmail.com \& romi_xiis2@yahoo.co.id \\ Jurusan Akuntansi Fakultas Ekonomi \\ Universitas Satya Negara Indonesia
}

\begin{abstract}
ABSTRAK
Penelitian ini bertujuan untuk menguji pengaruh profitabilitas, leverage, kompleksitas operasi perusahaan, reputasi KAP dan komite audit terhadap audit delay baik secara parsial maupun simultan. Penelitian ini merupakan jenis penelitian empiris yang menggunakan data sekunder berupa laporan keuangan tahunan. Populasi penelitian adalah seluruh perusahaan manufaktur yang terdaftar di Bursa Efek Indonesia tahun 2012 - 2014. Sampel yang digunakan adalah 239 perusahaan manufaktur yang diambil dengan teknik purposive sampling. Analisis yang digunakan adalah analisis regresi logistik pada tingkat signifikansi 5\% secara signifikan dengan menggunakan bantuan alat ukur SPSS 22.0. Hasil pengujian secara parsial menunjukan bahwa variabel yang mempengaruhi audit delay secara signifikan dan positif hanya variabel profitabilitas. Sedangkan variabel leverage, kompleksitas operasi perusahaan, reputasi KAP dan komite audit tidak mempengaruhi audit delay. Secara simultan profitabilitas, leverage, kompleksitas operasi perusahaan, reputasi KAP dan komite audit berpengaruh signifikan dan positif terhadap audit delay.
\end{abstract}

Kata kunci : Audit delay, profitabilitas, leverage, kompleksitas operasi perusahaan, reputasi KAP, komite audit

\section{ABSTRACT}

This research aimed to examine the effect of profitability, leverage, complexity of operations, reputable company KAP and the audit committee to audit delay either partially or simultaneously. This research is empirical research using secondary data from the annual financial statement. The study population was all manufacturing companies listed in Indonesia Stock Exchanges 2012 - 2014. The sample are 239 manufacturing companies that were taken by purposive sampling technique. The analysis used logistic regression analysis at a significance level of 5\% significanly with the help of measuring tools SPSS 22.0. The test result showed that the variables that effect audit delay was significanly and positively only variebel profitability. While the variable leverage, the complexity of operations, reputation company KAP and the audit committee doesn't effect audit delay. Simultaneously profitability, leverage, complexity of the companies operations, reputation public accounting firm and the audit committee significant and positive impact on the audit delay.

Keywords : audit delay, profitability, leverage, complexity of the companies operations, reputation public accounting firm and the audit committee. 


\section{PENDAHULUAN}

\section{Latar Belakang}

Semakin banyak informasi keuangan yang diperlukan seiring dengan banyaknya perusahaan yang go public. Informasi keuangan tersebut haruslah memberikan manfaat bagi penggunanya. Relevansi informasi keuangan dapat dilihat salah satunya dari ketepatwaktuan (timeliness) laporan keuangan tersebut disajikan. Laporan keuangan tahunan dan laporan auditor independen perusahaan publik paling lambat dilaporkan 90 hari setelah tanggal laporan keuangan tahunan pada BAPEPAM sesuai dengan Keputusan Ketua Bdan Pengawas Pasar Modal (BAPEPAM) Nomor Kep-36/PM/2003 tentang kewajiban penyampaian laporan keuangan berkala. Laporan keuangan perusahaan yang disampaikan ke BAPEPAM harus disertai laporan audit oleh akuntan publik. Untuk itu, laporan keuangan yang telah selesai disusun oleh perusahaan masih harus menjalani proses audit oleh auditor independen. Semakin panjang waktu yang dibutuhkan untuk proses audit, maka semakin besar kemungkinan bahwa perusahaan terlambat menyampaikan laporan keuangan ke BAPEPAM.

Hal inilah yang disebut dengan Audit Delay. Audit Delay merupakan rentang waktu laporan keuangan akhir tahun perusahaan hingga diterbitkannya opini audit oleh auditor independen walaupun hingga melewati batas ketentuan BAPEPAM. Berdasarkan penelitian sebelumnya masih terjadi research gap yang menunjukkan adanya keanekaragaman dari hasil penelitian tentang faktor-faktor yang mempengaruhi audit delay. Penelitian ini bermaksud untuk mempelajari lebih lanjut faktor-faktor yang mempengaruhi audit delay. Adapun penelitian sebelumnya yang melatarbelakangi penelitian ini yaitu penelitian yang dilakukan oleh Silvia dan Made (2013) mengenai pengaruh profitabilitas, leverage, kompleksitas operasi, reputasi KAP dan komite audit pada Audit Delay dengan Studi Empiris pada bidang industrial manufaktur di Bursa Efek Indonesia periode 2010-2011.

Dari penelitian tersebut peneliti ingin menguji kembali pengaruh profitabilitas, leverage, kompleksitas operasi, reputasi KAP dan komite audit pada Audit Delay tersebut apakah akan mendapatkan hasil yang sama apabila peneliti menerapkannya pada perusahaan - perusahaan manufaktur yang terdaftar di Bursa Efek Indonesia periode 2012 - 2014.

\section{Perumusan Masalah}

Berdasarkan uraian dalam latar belakang penelitian, tentang profitabilitas, leverage, kompleksitas operasi, reputasi KAP dan komite audit pada Audit Delay, pada perusahaan perusahaan manufaktur yang terdaftar di Bursa Efek Indonesia periode 2012 - 2014. maka masalah penelitian ini dapat dirumuskan sebagai berikut :

a. Apakah k profitabilitas mempunyai pengaruh terhadap Audit Delay?

b. Apakah leverage mempunyai pengaruh terhadap Audit Delay?

c. Apakah kompleksitas operasi mempunyai pengaruh terhadap Audit Delay?

d. Apakah reputasi KAP mempunyai pengaruh terhadap Audit Delay

e. Apakah komite audit mempunyai pengaruh terhadap Audit Delay

f. Apakah profitabilitas, leverage, kompleksitas operasi, reputasi KAP dan komite audit secara bersama-sama berpengaruh terhadap Audit Delay? 


\section{Tujuan dan Kegunaan Penelitian}

Tjuan yang ingin dicapai dalam penelitian ini adalah untuk mengatahui apakah ada pengaruh antara profitabilitas, leverage, kompleksitas operasi, reputasi KAP, komite audit, terhadap Audit Delay baik dengan cara masing-masing (Parsial) maupun dengan cara bersama-sama (simultan), serta untuk mengatahui apakah penelitian ini memiliki konsistensi yang sama dengan penelitian sebelumnya.

Penelitian dilakukan oleh peneliti dengan harapan dapat memberikan kegunaan menjadi referensi ilmiah tentang Pengaruh Antara Profitabilitas, Leverage, Kompleksitas Operasi, Reputasi KAP dan Komite Audit Terhadap Audit Delay pada Perusahaan Manufaktur yang Terdaftar Di Bursa Efek Indonesia dan dapat menjadi bahan referensi untuk memperbaiki atau pengembangan materi lain yang ingin mengkaji di bidang atau masalah yang sama serta dapat membantu memberikan kontribusi praktis bagi perusahaan manufaktur dalam menggambarkan ataupun memprediksikan lamanya Audit Delay dalam proses audit yang akan dilakukan.

\section{Laporan Keuangan}

\section{LANDASAN TEORI}

Keiso, Weygandt dan Warfield (2007:02) menyatakan bahwa "Laporan keuangan merupakan sarana pengkomunikasian informasi keuangan kepada pihak - pihak di luar perusahaan". Laporan ini menampilkan sejarah perusahaan yang dikuantifikasi dalam nilai moneter. Laporan keuangan yang lengkap biasanya meliputi neraca, laporan laba rugi, laporan arus kas, laporan perubahan ekuitas, catatan atas laporan keuangan atau pengungkapan juga merupakan bagian integral dari setiap laporan keuangan.

Laporan keuangan juga menunjukkan apa yang telah dilakukan manajemen (stewardship) atau pertanggungjawaban manajemen atas dasar sumber daya yang dipercayakan kepadanya. Atas dasar tujuan tersebut, diharapkan bahwa para pemakai laporan keuangan dapat menilai informasi yang dihasilkan untuk dasar pengambilan keputusan ekonomi yang berkaitan dengan perusahaan tersebut.

Karakteristik kualitas laporan keuangan sebagaimana yang dinyatakan Pernyataan Standar Akuntansi Keuangan dalam Kerangka Penyusunan Laporan Keuangan Tahun 2009 Paragraf 24 adalah:

a. Dapat dipahami

Kualitas penting informasi dalam laporan keuangan adalah kemudahannya untuk dapat dipahami oleh pengguna. Untuk maksud ini, pengguna diasumsikan memiliki pengetahuan yang memadai tentang aktivitas ekonomi dan bisnis, akuntansi, serta kemauan untuk mempelajari informasi dengan ketekunan yang wajar.

b. Relevan

Informasi harus relevan untuk memenuhi kebutuhan pengguna dalam proses pengambilan keputusan. Informasi memiliki kualitas relevan apabila dapat mempengaruhi keputusan ekonomi pengguna, dengan membantu mengevaluasi peristiwa masa lalu, masa kini dan masa depan

c. Keandalan Informasi juga harus andal (reliable). Informasi memiliki kualitas andal jika bebas dari pengertian yang menyesatkan, kesalahan material, dan dapat diandalkan 
penggunaannya sebagai penyajian yang tulus atau jujur (faithful representation) dari yang seharusnya disajikan atau yang secara wajar diharapkan dapat disajikan.

d. Dapat dibandingkan

Pengguna harus dapat memperbandingkan laporan keuangan perusahaan antar periode untuk mengidentifikasikan kecenderungan (trend) posisi dan kinerja keuangan. Pengguna juga harus dapat memperbandingkan laporan keuangan antar perusahaan untuk mengevaluasi posisi keuangan, kinerja, serta perubahan posisi keuangan secara relatif.

\section{Audit Delay}

Menurut Sistya Rachmawati (2008) dimana audit delay adalah rentang waktu penyelesaian audit laporan keuangan tahunan, diukur berdasarkan lamanya hari yang dibutuhkan untuk memperoleh laporan auditor independen atas audit laporan keuangan tahunan perusahaan, sejak tanggal tahun tutup buku perusahaan sampai dengan tanggal yang tertera pada laporan auditor independen. Panjangnya masa audit delay ini berbanding lurus dengan lamanya masa pekerjaan lapangan diselesaikan auditor sehingga semakin lama pekerjaan lapangan maka semakin lama audit delay yang terjadi. Apabila laporan keuangan disajikan delay maka informasi yang terkandung di dalamnya menjadi tidak relevan dalam pengambilan keputusan.

\section{Profitabilitas}

Profitabilitas atau disebut juga rentabilitas adalah mengukur kemampuan perusahaan dalam menghasilkan laba dengan menggunakan sumber yang ada pada perusahaan. Menurut Hanafi $(2012 ; 81)$ "Rasio profitabilitas dapat mengukur kemampuan perusahaan menghasilkan keuntungan pada tingkat penjualan, aset, dan modal saham". Menurut CheAhmad (2008) yang dikutip dari Angruningrum (2013) menyatakan bahwa apabila profitabilitas perusahaan rendah, maka auditor akan melakukan tugas auditnya dengan lebih hati-hati karena adanya resiko bisnis yang lebih tinggi sehingga akan memperlambat proses audit dan menyebabkan penerbitan laporan auditan yang lebih panjang.

\section{Leverage}

Menurut Febrianty (2011) rasio Leverage merupakan kemampuan perusahaan dalam memenuhi liabilitasnya. Harahap (2006;306) menyatakan bahwa rasio leverage menggambarkan hubungan antara utang perusahaan terhadap modal maupun aset dan rasio ini dapat melihat seberapa jauh perusahaan dibiayai oleh utang atau pihak luar dengan kemampuan perusahaan yang digambarkan oleh modal (equity). Perusahaan yang baik mestinya memiliki komposisi modal yang lebih besar dari utang dan rasio ini bisa juga dianggap bagian dari rasio solvabilitas.

\section{Kompleksitas Operasi}

Menurut Che-Ahmad (2008) dikutip dari Angruningrum (2013;255) menyatakan bahwa jumlah anak perusahaan yang dimiliki perusahaan mencerminkan bahwa perusahaan memiliki unit operasi yang lebih banyak yang harus diperiksa dalam setiap transaksi dan catatan yang menyertainya. Tingkat ini lebih cenderung mempengaruhi waktu yang dibutuhkan auditor untuk menyelesaikan sehingga hal tersebut juga mempengaruhi waktu dimana perusahaan pada akhirnya mengeluarkan laporan keuangannya kepada publik. 


\section{Reputasi KAP}

Perusahaan dalam menyampaikan suatu laporan atau informasi akan kinerja perusahaan kepada para pihak agar akurat dan terpercaya diminta untuk menggunakan jasa Kantor Akuntan Publik (KAP). Untuk meningkatkan kemampuan dari laporan itu, perusahaan menggunakan jasa KAP yang mempunyai reputasi atau nama baik. Menurut Lee (2008) yang dikutip dari Angruningrum $(2013 ; 256)$ mengemukakan bahwa KAP yang berafiliasi dengan Big Four lebih awal menyelesaikan auditnya daripada KAP non-Big Four. Karena, KAP Big Four diperkirakan memiliki ketersediaan teknologi yang lebih maju dan staf spesialis sehingga akan lebih efisien dalam melakukan pelayanan mereka.

\section{Komite Audit}

Pemerintah mengeluarkan beberapa peraturan bagi perusahaan publik untuk mencapai good corporate governance antara lain BAPEPAM dengan Surat Edaran No. SE-03/PM/2000 dikutip dari Angruningrum $(2013 ; 256)$ mensyaratkan bahwa setiap perusahaan go public di Indonesia wajib membentuk komite audit dengan anggota minimal 3 orang yang diketuai oleh satu orang komisaris independen perusahaan dan dua orang dari luar perusahaan yang independen terhadap perusahaan. Selain bersifat independen dua orang tersebut juga disyaratkan harus menguasai dan memiliki latar belakang akuntansi dan keuangan jika ia anggota komite audit yang sesuai dengan surat edaran tersebut

\section{Hubungan Profitabilitas dengan Audit Delay}

Menurut Rachmawati (2008) yang dikutip dari Angruningrum (2013) menyatakan bahwa profitabilitas menggambarkan tingkat efektivitas kegiatan operasional yang dapat dicapai perusahaan. Menurut Che-Ahmad (2008) yang dikutip dari Angruningrum (2013) menyatakan bahwa apabila profitabilitas perusahaan rendah, maka auditor akan melakukan tugas auditnya dengan lebih hati-hati karena adanya resiko bisnis yang lebih tinggi sehingga akan memperlambat proses audit dan menyebabkan penerbitan laporan auditan yang lebih panjang. Dugaan hipotesis yang akan dilakukan adalah berikut ini .

$\mathrm{H}_{1}$ : Profitablitas berpengaruh positif dengan audit delay

\section{Hubungan Leverage dengan Audit Delay}

Harahap (2006;306) menyatakan bahwa rasio leverage menggambarkan hubungan antara utang perusahaan terhadap modal maupun aset dan rasio ini dapat melihat seberapa jauh perusahaan dibiayai oleh utang atau pihak luar dengan kemampuan perusahaan yang digambarkan oleh modal (equity). Apabila perusahaan memiliki rasio leverage yang tinggi maka resiko kerugian perusahaan tersbut akan bertambah. Oleh sebab itu, untuk memperoleh keyakinan akan laporan keuangan perusahaan maka auditor akan meningkatkan kehatihatiannya sehingga rentang audit delay akan lebih panjang. Dugaan hipotesis yang akan dilakukan adalah berikut ini .

$\mathrm{H}_{2}$ : Leverage tidak berpengaruh dan negatif dengan audit delay

\section{Hubungan Kompleksitas Operasi dengan Audit Delay}

Menurut Che-Ahmad (2008) dikutip dari Angruningrum (2013;255) menyatakan bahwa jumlah anak perusahaan yang dimiliki perusahaan mencerminkan bahwa perusahaan memiliki unit operasi yang lebih banyak yang harus diperiksa dalam setiap transaksi dan 
catatan yang menyertainya. Tingkat ini lebih cenderung mempengaruhi waktu yang dibutuhkan auditor untuk menyelesaikan sehingga hal tersebut juga mempengaruhi waktu dimana perusahaan pada akhirnya mengeluarkan laporan keuangannya kepada publik. Apabila perusahaan memiliki anak perusahaan, maka perusahaan akan mengkonsolidasikan laporan keuangannya. Selanjutnya, auditor akan mengaudit laporan konsolidasi perusahaan tersebut. Hal ini akan membuat ruang lingkup audit semakin luas dan berdampak pada waktu yang dibutuhkan auditor dalam menyelesaikan laporan auditnya. Dugaan hipotesis yang akan dilakukan adalah berikut ini .

$\mathrm{H}_{3}$ : Kompleksitas operasi tidak berpengaruh dan negatif dengan audit delay

\section{Hubungan Reputasi KAP dengan Audit Delay}

Perusahaan dalam menyampaikan suatu laporan atau informasi akan kinerja perusahaan kepada para pihak agar akurat dan terpercaya diminta untuk menggunakan jasa Kantor Akuntan Publik (KAP). Untuk meningkatkan kemampuan dari laporan itu, perusahaan menggunakan jasa KAP yang mempunyai reputasi atau nama baik. Menurut Lee (2008) yang dikutip dari Angruningrum $(2013 ; 256)$ mengemukakan bahwa KAP yang berafiliasi dengan Big Four lebih awal menyelesaikan auditnya daripada KAP non-Big Four. Karena, KAP Big Four diperkirakan memiliki ketersediaan teknologi yang lebih maju dan staf spesialis sehingga akan lebih efisien dalam melakukan pelayanan mereka. Dugaan hipotesis yang akan dilakukan adalah berikut ini .

$\mathrm{H}_{4}$ : Reputasi KAP tidak berpengaruh dan negatif dengan audit delay

\section{Hubungan Komite Audit dengan Audit Delay}

Pemerintah mengeluarkan beberapa peraturan bagi perusahaan publik untuk mencapai good corporate governance antara lain BAPEPAM dengan Surat Edaran No. SE-03/PM/2000 dikutip dari Angruningrum $(2013 ; 256)$ mensyaratkan bahwa setiap perusahaan go public di Indonesia wajib membentuk komite audit dengan anggota minimal 3 orang yang diketuai oleh satu orang komisaris independen perusahaan dan dua orang dari luar perusahaan yang independen terhadap perusahaan. Selain bersifat independen dua orang tersebut juga disyaratkan harus menguasai dan memiliki latar belakang akuntansi dan keuangan jika ia anggota komite audit yang sesuai dengan surat edaran tersebut. Dugaan hipotesis yang akan dilakukan adalah berikut ini .

$\mathrm{H}_{5}$ : Komite Audit tidak berpengaruh dan negatif dengan audit delay

\section{METODOLOGI PENELITIAN}

Penelitian ini dilakukan di Bursa Efek Indonesia (BEI), Jalan Jendral Sudirman, Jakarta Selatan atau dengan melalui website $w w w . i d x . c o . i d$. Metode penelitian ini adalah penelitian kausal komparatif yang juga merupakan penelitian ex post facto, yaitu tipe penelitian terhadap data yang dikumpulkan setelah terjadinya suatu fakta atau peristiwa. Data yang digunakan dalam penelitian ini adalah data sekunder dengan dapat diartikan bahwa data yang diperoleh dalam penelitian ini berasal dari pihak ketiga yang menyediakan data yang dibutuhkan dalam penelitian. Penelitian ini menggunakan teknik dokumentasi dalam mengumpulan data sekundernya. 
Dalam penelitian ini, populasinya adalah perusahaan yang terdaftar di Bursa Efek Indonesia dari tahun 2012 - 2014. Sampelnya adalah perusahaan manufaktur yang terdaftar di Bursa Efek Indonesia dari tahun 2012-2014. Pengambilan sampel dalam penelitian ini menggunakan metode Puposive Sampling dengan kriteria yaitu Data perusahaan manufaktur yang telah terdaftar di Bursa Efek Indonesia yang bisa didapat atau yang diperoleh, Mempublikasi laporan tahunan perusahaan dan laporan keuangan telah diaudit secara lengkap yang berakhir pada 31 Desember, Perusahaan yang menggunakan satuan moneter rupiah (Rp) dalam pelaporannya, Perusahaan yang memiliki laba bersih, Return Of Asset (ROA) dan Dept Equity Ratio (DER) positif selama periode penelitian, dan Memiliki data yang diperlukan untuk mendukung penelitian seperti latar belakang bidang komite audit. Analisis yang digunakan dalam penelitian ini adalah analisis statistik deskriptif dan regresi logistik (logistic regression) dengan bantuan alat ukur SPSS 22.0. Analisis ini digunakan karena variabel terikat (dependent) yang bersifat dummy atau dikotomi dan variabel bebas (independent) yang bersifat dummy atau dikotomi dan rasio. Model analisis logistic regression yang digunakan adalah sebagai berikut :

$$
\operatorname{Ln}(\mathrm{TL} / 1-\mathrm{TL})=\mathrm{a}+\mathrm{b}_{1} \mathrm{X}_{1}+\mathrm{b}_{2} \mathrm{X}_{2}+\mathrm{b}_{3} \mathrm{X}_{3}+\mathrm{b}_{4} \mathrm{X}_{4}+\mathrm{b}_{5} \mathrm{X}_{5}+\mathrm{e}
$$

Keterangan :

$$
\begin{array}{ll}
\operatorname{Ln}(\mathrm{TL} / 1-\mathrm{TL})=\text { Simbol untuk Audit Delay } \\
\mathrm{a} & =\text { Konstanta } \\
\mathrm{b}_{1} \mathrm{X}_{1} & =\text { Koefisien Profitabilitas } \\
\mathrm{b}_{2} \mathrm{X}_{2} & =\text { Koefisien Leverage } \\
\mathrm{b}_{3} \mathrm{X}_{3} & =\text { Koefisien Kompleksitas Operasi } \\
\mathrm{b}_{4} \mathrm{X}_{4} & =\text { Koefisien Reputasi KAP } \\
\mathrm{b}_{5} \mathrm{X}_{5} & =\text { Koefisien Komite Audit } \\
\mathrm{e} & =\text { Error atau faktor lain yang mempengaruhi audit delay }
\end{array}
$$

Variabel Independen $\quad$ Variabel Dependen

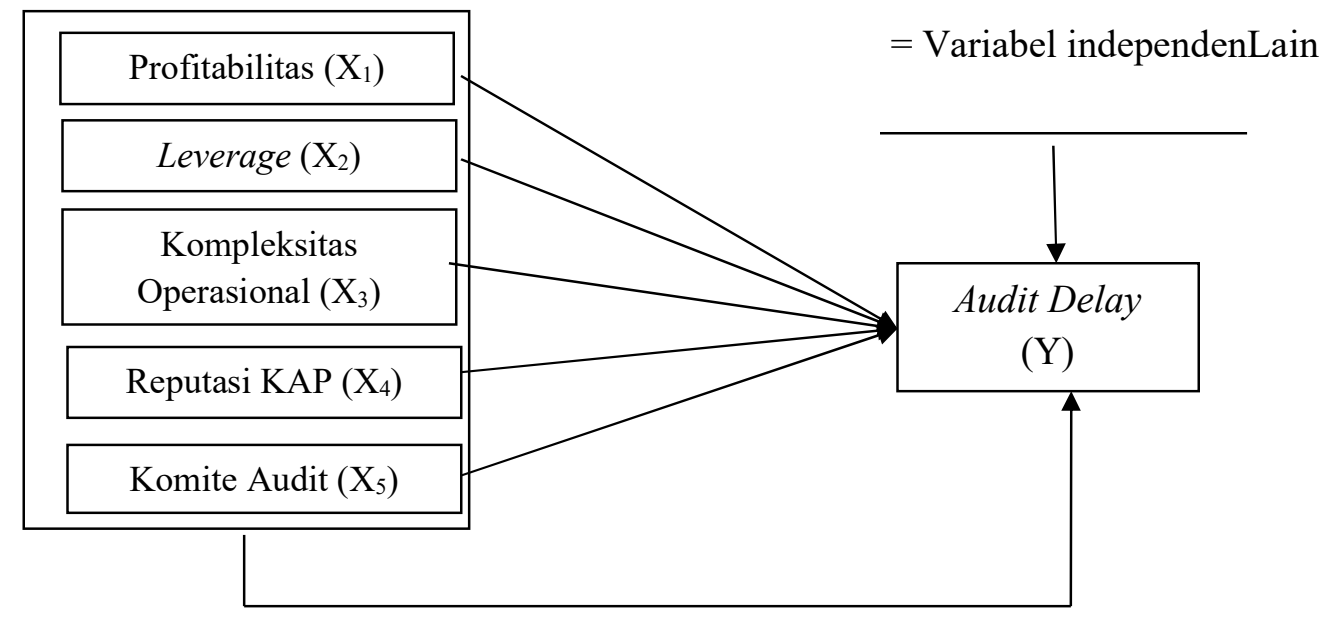

Sumber : Diolah sendiri 


\section{Definisi Operasional Vaiabel}

\section{Audit Delay}

Variabel Terikat merupakan variabel yang dipengaruhi atau yang menjadi akibat karena adanya variabel bebas. Dalam penelitian ini yang menjadi variabel terikat (Y) adalah Audit Delay yang bersifat dummy. Dengan diukur berdasarkan ketepatan waktu dalam penyampaian laporan keuangan. Seperti apabila perusahaan tidak terlambat dalam penyampaian laporan keuangannya diberi nilai 1 dan apabila perusahaan terlambat dalam penyampaian laporan keuangannya diberi nilai 2 .

\section{Profitabilitas}

Profitabilitas merupakan kemampuan perusahaan memanfaatkan asset yang ada untuk menghasilkan pendapatan. Variabel ini diprediksi melalui return on assets (ROA) dalam pengukurannya. Rumusnya adalah sebagai berikut :

$$
\boldsymbol{R O A}=\frac{\text { Laba Bersih Setelah Pajak }}{\text { Total Aktiva }} \times 100 \%
$$

\section{Leverage}

Leverage adalah kemampuan perusahaan untuk memenuhi kewajiban jangka panjang / kewajiban - kewajibannya. Variabel ini diprediksi melalui Debt to Equity Ratio (DER) dalam pengkurannya. Rumusnya adalah sebagai berikut :

$$
\boldsymbol{D E} \boldsymbol{R}=\frac{\text { Total Kewajiban }}{\text { Total Ekuitas }} \times 100 \%
$$

\section{Kompleksitas Operasi}

Dalam variabel kompleksitas operasi yang bersifat dummy diukur dengan membandingkan keberadaan anak perusahaan. Seperti apabila perusahaan memiliki anak perusahaan diberi nilai 1 dan apabila perusahaan tidak memiliki, diberi nilai 0 .

\section{Reputasi KAP}

Dalam variabel reputasi KAP ini yang bersifat dummy dengan pengukuran berdasarkan Kantor Akuntan Publik (KAP) yang berafiliasi dengan KAP non Big Four dan Big Four. Seperti apabila perusahaan diaudit oleh KAP lokal yang berafiliasi dengan KAP Big Four maka diberi nilai 1 dan apabila perusahaan diaudit oleh KAP lokal yang tidak berafiliasi dengan KAP Big Four maka diberi nilai 0.

\section{Komite Audit}

Variabel komite audit dalam penelitian ini diukur dengan cara membandingkan jumlah anggota konite audit yang memiliki latarbelakang akuntansi dan keuangan dengan total jumlah anggota komite audit beserta ketua komite audit. Komite audit diukur dengan cara sebagai berikut (Angruningrum, 2013;259): 


$$
=\frac{\text { Jumlah komite audit yang memiliki latar belakang Akuntansi dan atau Keuangan }}{\times 100 \%}
$$

\section{ANALISIS DAN PEMBAHASAN}

Hasil dari seleksi sampel yang menggunakan teknik purposive sampling hingga menghasilkan 293 sampel yang lolos di seleksi disajikan dalam table berikut :

Tabel

Proses seleksi sampel dengan kriteria

\begin{tabular}{|c|l|c|c|}
\hline No. & \multicolumn{1}{|c|}{ Kriteria } & $\begin{array}{c}\text { Tidak Memenuhi } \\
\text { Kriteria }\end{array}$ & Akumulasi \\
\hline 1. & $\begin{array}{l}\text { Data perusahaan manufaktur yang telah } \\
\text { terdaftar di Bursa Efek Indonesia selama } \\
\text { periode tahun 2012 - 2014 yang bisa didapat } \\
\text { atau yang diperoleh }\end{array}$ & 435 \\
\hline 2. & $\begin{array}{l}\text { Mempublikasi laporan tahunan perusahaan } \\
\text { dan laporan keuangan telah diaudit secara } \\
\text { lengkap yang berakhir pada 31 Desember } \\
\text { selama periode tahun 2012-2014 }\end{array}$ & 30 & 405 \\
\hline 3. & $\begin{array}{l}\text { Perusahaan yang menggunakan satuan } \\
\text { moneter rupiah (Rp) dalam pelaporannya }\end{array}$ & 91 & 314 \\
\hline 4. & $\begin{array}{l}\text { Perusahaan yang memiliki laba bersih, } \\
\text { Return Of Asset (ROA) dan Dept Equity } \\
\text { Ratio (DER) positif selama periode } \\
\text { penelitian }\end{array}$ & 32 & 282 \\
\hline 5. & $\begin{array}{l}\text { Memiliki data yang diperlukan untuk } \\
\text { mendukung penelitian seperti latar belakang } \\
\text { bidang komite audit }\end{array}$ & 43 & 239 \\
\hline & \multicolumn{1}{|c|}{ Total Sampel } & 239 \\
\hline
\end{tabular}

Sumber : data diolah sendiri,

\section{Analisis Statistik Deskriptif}

Tabel

Statistik Deskriptif Variabel-Variabel Penelitian

Descriptive Statistics

\begin{tabular}{|l|r|r|r|r|r|r|}
\hline & \multicolumn{1}{|c|}{$\mathrm{N}$} & Minimum & Maximum & \multicolumn{2}{|c|}{ Mean } & Std. Deviation \\
\cline { 2 - 7 } & Statistic & Statistic & Statistic & Statistic & Std. Error & \multicolumn{1}{c|}{ Statistic } \\
\hline Audit Delay & 239 & 1 & 2 & 1,01 &, 006 &, 091 \\
Profitabilitas & 239 &, 04 & 7,69 & 1,0585 &, 07351 & 1,13648 \\
Leverage & 239 &, 00 & 1,11 &, 0953 &, 00777 &, 12018 \\
Kompleksitas Operasi & 239 & 0 & 1 &, 67 &, 030 &, 470 \\
Reputasi KAP & 239 & 0 & 1 &, 38 &, 031 &, 486 \\
Komite Audit & 239 &, 33 & 1,00 &, 6226 &, 01134 &, 17536 \\
Valid N (listwise) & 239 & & & & & \\
\hline
\end{tabular}


Berdasarkan hasil perhitungan pada tabel terdapat 239 sampel dan menunjukkan hasil nilai masing-masing variabel. Berikut penjelasannya :

1. Audit delay karena variabel ini bersifat dummy maka nilai minimumnya 1 untuk perusahaan yang tidak terlambat dalam menyampaikan laporan keuangannya dan maximumnya 2 untuk perusahaan yang terlambat dalam menyampaikan laporan keuangannya. Serta mean dari audit delay sebesar 1.01 yang lebih besar dari standar errornya sebesar 0.006 dengan standar deviasi sebesar 0.091 .

2. Hasil uji statistik deskriptif pada tabel di atas menunjukkan bahwa minimum profitabilitas sebesar 0.04 yang diperoleh PT KMI Wire and Cable Tbk. tahun 2012 dan maksimum profitabilitas sebesar 7.69 yang diperoleh PT Tirta Mahakam Resources Tbk. Serta dengan mean sebesar 1,0585 lebih besar dari standar errornya sebesar 0.07351 dengan standar deviasi sebesar 1.13648 .

3. Hasil uji statistik deskriptif pada tabel di atas menunjukkan bahwa minimum Leverage sebesar 0.00 yang diperoleh 15 perusahaan manufaktur yang terdaftar di BEI tahun 2012 hingga 2014 dan maksimum Leverage sebesar 1.11 yang diperoleh PT Indofoos CBP Sukses Makmur Tbk. Serta dengan mean sebesar 0.0953 lebih besar dari standar errornya sebesar 0.0078 dengan standar deviasi sebesar 0.12018 .

4. Kompleksitas operasi karena variabel ini bersifat dummy maka nilai minimumnya 0 untuk perusahaan yang tidak memiliki anak perusahaan dan maximumnya 1 untuk perusahaan yang memiliki anak perusahaan. Serta mean dari kompleksitas operasi sebesar 0.67 yang lebih besar dari standar errornya sebesar 0.030 dengan standar deviasi sebesar 0.470

5. Reputasi KAP karena variabel ini bersifat dummy maka nilai minimumnya 0 untuk perusahaan yang tidak diaudit dari KAP yang berafiliasi dengan KAP Big Four dan maximumnya 1 untuk perusahaan perusahaan yang diaudit dari KAP yang berafiliasi dengan KAP Big Four. Serta mean dari reputasi KAP sebesar 0.38 yang lebih besar dari standar errornya sebesar 0.031 dengan standar deviasi sebesar 0.486 .

6. Hasil uji statistik deskriptif pada tabel di atas menunjukkan bahwa minimum komite audit sebesar 0.33 yang diperoleh 48 perusahaan manufaktur yang terdaftar di BEI tahun 2012 hingga 2014 dan maksimum komite audit sebesar 1.11 yang diperoleh 19 perusahaan manufaktur yang terdaftar di BEI tahun 2012 hingga 2014. Serta dengan mean sebesar 0.0953 lebih besar dari standar errornya sebesar 0.01134 dengan standar deviasi sebesar 0.17536 .

\section{Analisis Regresi Logistik}

\section{Pengujian kelayakan model regresi (Goodness of Fitness Test)}

Adapun hipotesis yang digunakan untuk menilai kelayakan model regresi adalah :

$\mathrm{HO}$ : Tidak ada perbedaan yang nyata antara klasifikasi yang diprediksi dengan klasifikasi yang diamati

H1 : Tidak ada perbedaan yang nyata antara klasifikasi yang diprediksi dengan klasifikasi yang diamati 
Tabel

Hasil Uji Kelayakan Model Regresi

Hosmer and Lemeshow Test

\begin{tabular}{|l|r|r|r|}
\hline Step & Chi-square & Df & \multicolumn{1}{c|}{ Sig. } \\
\hline 1 & 7,530 & &, 481 \\
\hline
\end{tabular}

Sumber : Hasil analisis data dengan SPSS 22.0

Hasil pengujian statistik menunjukkan chi-square 7.530 dengan nilai signifikan $0.481>$ 0.05, maka H0 diterima. Hal ini berarti tidak ada perbedaan antara model dengan data. Dengan demikian dapat disimpulkan bahwa model mampu memprediksi nilai observasi atau dapat dikatakan model dapat diterima karena cocok dengan data observasinya.

\section{Pengujian Model Fit dan Keseluruhan Model (Overall Model Fit)}

Hipotesis untuk menilai model fit adalah :

H0 : Model yang dihipotesiskan fit dengan data

$\mathrm{H}_{1}$ : Model yang dihipotesiskan tidak fit dengan data

Pengujian dilakukan dengan membandingkan nilai antara -2 Log likelihood awal dan akhir dengan kriteria apabila nilai hasil -2 Log likelihood awal ada penurunan pada hasil -2 Log likelihood akhir maka model dinyatakan fit dengan data atau sebaliknya. Hasil -2 Log likelihood awal dapat dilihat pada tabel 4.4 literation History dalam output SPSS.

\section{Tabel}

Hasil Pengujian Model Fit (-2 Log likelihood awal)

\begin{tabular}{|ll|r|r|}
\multicolumn{5}{|c|}{ Iteration History $\mathbf{a , b , c}$} \\
\hline \multirow{2}{*}{ Iteration } & & & Coefficients \\
\cline { 4 - 4 } & & -2 Log likelihood & Constant \\
\hline & 1 & 70,473 & $-1,967$ \\
& 2 & 34,697 & $-3,029$ \\
& 3 & 25,251 & $-3,887$ \\
& 4 & 23,303 & $-4,483$ \\
& 5 & 23,119 & $-4,737$ \\
& 6 & 23,116 & $-4,774$ \\
& 7 & 23,116 & $-4,775$ \\
\hline
\end{tabular}

a. Constant is included in the model.

b. Initial -2 Log Likelihood: 23,116

c. Estimation terminated at iteration number 7 because parameter estimates changed by less than, 001 .

Sumber : Hasil pengolahan data dengan menggunakan SPSS 22.0

Tabel di atas adalah Iteration History 0 yang merupakan -2 Log likelihood awal yaitu sebesar 23.116. Nilai yang tertera dalam tabel digunakan untuk dibandingkan dengan nilai Iteration History 1 yang merupakan -2 Log likelihood akhir. Adanya pengurangan antara -2 Log likelihood awal dengan -2 Log likelihood akhir menunjukkan bahwa model yang dihipotesiskan fit dengan data. 


\section{Tabel}

Hasil Pengujian Model Fit (-2 Log likelihood akhir)

Iteration History $\mathbf{a}, \mathrm{b}, \mathbf{c}, \mathrm{d}$

\begin{tabular}{|l|r|r|r|r|r|r|r|}
\hline & \multirow{2}{*}{ Iteration } & \multirow{2}{*}{$\begin{array}{c}\text {-2 Log } \\
\text { likelihood }\end{array}$} & \multicolumn{7}{|c|}{ Coefficients } \\
\cline { 5 - 8 } & Constant & \multicolumn{1}{c|}{ X1 } & \multicolumn{1}{c|}{ X2 } & \multicolumn{1}{c|}{ X3 } & X4 & \multicolumn{1}{c|}{ X5 } \\
\hline Step 1 1 & 70,038 & $-2,036$ &, 058 &,- 037 &,- 039 &, 039 &, 037 \\
& 33,421 & $-3,236$ &, 165 &,- 132 &,- 119 &, 124 &, 114 \\
& 22,654 & $-4,377$ &, 339 &,- 446 &,- 285 &, 330 &, 293 \\
& 19,469 & $-5,425$ &, 506 & $-1,382$ &,- 545 &, 741 &, 630 \\
& 18,639 & $-6,186$ &, 608 & $-3,405$ &,- 814 & 1,276 & 1,015 \\
& 18,472 & $-6,418$ &, 646 & $-6,217$ &,- 976 & 1,635 & 1,130 \\
& 18,454 & $-6,386$ &, 652 & $-8,011$ & $-1,024$ & 1,738 & 1,102 \\
6 & 18,454 & $-6,375$ &, 652 & $-8,346$ & $-1,029$ & 1,749 & 1,097 \\
7 & 18,454 & $-6,374$ &, 652 & $-8,354$ & $-1,029$ & 1,749 & 1,097 \\
8 & 18,454 & $-6,374$ &, 652 & $-8,354$ & $-1,029$ & 1,749 & 1,097 \\
\hline
\end{tabular}

a. Method: Enter

b. Constant is included in the model.

c. Initial -2 Log Likelihood: 23,116

d. Estimation terminated at iteration number 10 because parameter estimates changed by less than ,001.

Sumber : Hasil pengolahan data dengan menggunakan SPSS 22.0

Pada tabel menunjukkan bahwa nilai -2 Log likelihood akhir adalah sebesar 18.454. Hal ini berarti nilai -2 Log likelihood mengalami penurunan pada nilai akhir yaitu dari nilai awal sebesar 23.116 menjadi 18.454, yang menunjukkan bahwa model yang dihipotesiskan fit dengan data.

\section{Uji Koefisien Regresi (Uji Parsial)}

Pengujian dilakukan dengan menggunakan hasil uji regresi logistik yang ditunjukkan dalam variebles in the equation pada kolom significant yang dibandingkan dengan tingkat kealpaan 5\%. Apabila tingkat signifikansi < 0.05, maka Ha diterima. Hasil uji menunjukkan table 4.6 berikut .

\section{Tabel}

\section{Koefisien Regresi Model}

Variables in the Equation

\begin{tabular}{|rl|r|r|r|r|r|r|}
\hline & \multicolumn{1}{|c|}{ B } & \multicolumn{1}{c|}{ S.E. } & \multicolumn{1}{c|}{ Wald } & Df & \multicolumn{1}{c|}{ Sig. } & \multicolumn{1}{c|}{ Exp(B) } \\
\hline Step 1 ${ }^{\mathrm{a}}$ & X1 &, 652 &, 338 & 3,727 & &, 036 & 1,920 \\
& $-8,354$ & 18,564 &, 203 & 1 &, 653 &, 000 \\
& X2 & $-1,029$ & 1,526 &, 455 & 1 &, 500 &, 357 \\
X3 & 1,749 & 1,848 &, 896 & 1 &, 344 & 5,751 \\
X4 & 1,097 & 5,451 &, 041 & 1 &, 840 & 2,995 \\
X5 & $-6,374$ & 4,063 & 2,461 & 1 &, 117 &, 002 \\
\hline
\end{tabular}


a. Variable(s) entered on step 1: X1, X2, X3, X4, X5.

Sumber : Hasil pengolahan data SPSS 22.0

Hasil analisis regresi logistik pada tabel pengujian koefisien regresi untuk masingmasing variabel adalah sebagai berikut :

\section{Pengaruh Profitabilitas Terhadap Audit Delay}

Berdasarkan hasil dari pengujian secara parsial pengaruh profitabilitas terhadap audit delay dengan menggunakan SPSS diperoleh koefisien regresi positif sebesar 0.652 dengan tingkat signifikan 0.036 yang kurang dari 0.05 . Berdasarkan hal tersebut dapat disimpulkan bahwa variabel profitabilitas berpengaruh signifikan dan positif terhadap audit delay atau dengan kata lain $\mathrm{Ha}_{1}$ diterima.

\section{Pengaruh Leverage Terhadap Audit Delay}

Berdasarkan hasil dari pengujian secara parsial pengaruh leverage terhadap audit delay dengan menggunakan SPSS diperoleh koefisien regresi negatif sebesar -8.354 dengan tingkat signifikansi sebesar 0.653 yang lebih besar dari 0.05. Berdasarkan hal tersebut dapat disimpulkan bahwa variabel leverage tidak berpengaruh signifikan dan negative terhadap audit delay atau dengan kata lain $\mathrm{Ha}_{2}$ ditolak.

\section{Pengaruh Kompleksitas Operasi Terhadap Audit Delay}

Berdasarkan hasil dari pengujian secara parsial pengaruh kompleksitas operasi terhadap audit delay dengan menggunakan SPSS diperoleh koefisien regresi negatif sebesar -1.029 dengan tingkat signifikansi sebesar 0.50 yang lebih besar dari 0.05 . Berdasarkan hal tersebut dapat disimpulkan bahwa variabel kompleksitas operasi tidak berpengaruh signifikan dan negative terhadap audit delay atau dengan kata lain $\mathrm{Ha}_{3}$ ditolak

\section{Pengaruh Reputasi KAP Terhadap Audit Delay}

Berdasarkan hasil dari pengujian secara parsial pengaruh reputasi KAP terhadap audit delay dengan menggunakan SPSS diperoleh koefisien regresi positif 1.749 dengan tingkat signifikansi 0.344 yang lebih besar dari 0.05 . Berdasarkan hal tersebut dapat disimpulkan bahwa reputasi KAP tidak berpengaruh signifikan dan positif terhadap audit delay atau dengan kata lain $\mathrm{Ha}_{4}$ ditolak.

\section{Pengaruh Komite Audit Terhadap Audit Delay}

Berdasarkan hasil dari pengujian secara parsial pengaruh komite audit terhadap audit delay dengan menggunakan SPSS diperoleh koefisien regresi positif 1.097 dengan tingkat signifikansi 0.840 yang lebih dari 0.05 . Berdasarkan hal tersebut dapat disimpulkan bahwa variabel komite audit tidak berpengaruh signifikan dan positif terhadap audit delay atau dengan kata lain $\mathrm{Ha}_{5}$ ditolak

\section{Uji Omnibus Tests of Model Coefficients (Uji Simultan)}

Dalam penelitian ini uji omnibus test of model coeficients bertujuan untuk menguji pengaruh lima variabel bebas tersebut (profitabilitas, leverage, kompleksitas operasi, reputasi 
kap dan komite audit) terhadap audit delay secara simultan (bersama-sama). Apabila tingkat signifikannya $>0.05$ maka tidak terdapat pengaruh yang signifikan dari variabel bebas terhadap variabel terikat. Begitu juga sebaliknya tingkat signifikannya $<0.05$ maka terdapat pengaruh yang signifikan dari variabel bebas terhadap variabel terikat. Uji Omnibus Tests of Model Coefficients dapat dilihat pada table berikut .

Tabel

Hasil Pengujian Secara Simultan

Omnibus Tests of Model Coefficients

\begin{tabular}{|ll|r|r|r|}
\hline & & & & \multicolumn{1}{c|}{ Chi-square } \\
Step 1 & Step & 4,663 & 5 &, 026 \\
& & 4,663 & 5 &, 026 \\
& Block & 4,663 & 5 &, 026 \\
\hline
\end{tabular}

Sumber : Hasil pengolahan data SPSS 22.0

Berdasarkan tabel di atas menunjukkan hasil secara simultan pengaruh profitabilitas, leverage, kompleksitas operasi, reputasi KAP dan komite audit adalah signifikan dan positif terhadap audit delay.

Berdasarkan tabel di atas Chi-square sebesar 4.663 dengan tingkat signifikansi $0.026<$ 0.05 maka dapat disimpulkan bahwa profitabilitas, leverage, kompleksitas operasi, reputasi kap dan komite audit secara simultan berpengaruh signifikan dan positif terhadap audit delay. Maka dengan kata lain $\mathrm{Ha}_{6}$ diterima.

\section{Pengujian Hipotesis}

\section{Hipotesis Pertama}

\section{Ha1 : Ada pengaruh profitabilitas pada audit delay.}

Pada tabel profitabilitas yang dihitung dengan rumus laba bersih setelah pajak dibagi dengan total aset memiliki koefisien regresi positif 0.652 dengan tingkat signifikan 0.036 yang kurang dari 0.05. Berdasarkan hal tersebut dapat disimpulkan bahwa variabel profitabilitas berpengaruh signifikan dan positif terhadap audit delay.

Hasil dari penelitian ini sejalan dengan hasil penelitian yang dilakukan oleh Utari Hilmi dan Syaiful Ali (2008) dan Novi Wiji Lestari (2012). Dimana hasil penelitian yang dilakukan menyatakan bahwa profitabilitas perusahaan dapat berpengaruh signifikan terhadap Audit Delay. Namun hasil penelitian ini tidak sejalan dengan hasil penelitian yang dilakukan oleh Andi Kartika (2009). Karena hasil penelitian yang dilakukan Andi Kartika (2009) menyatakan bahwa profitabilitas tidak berpengaruh tidak signifikan terhadap Audit Delay. Perbedaan ini dapat dikarenakan pemilihan sampel dan periode tahun laporan keuangan yang berbeda serta analisis regresi yang digunakan.

Dengan demikian dapat dinyatakan bahwa jika suatu perusahaan dengan tingkat profitabilitas tinggi yang mana merupakan suatu sinyal yang bagus, maka hal ini menjadi berita baik dan perusahaan cenderung untuk menyampaikan laporan keuangan secara tepat waktu kepada pihak-pihak yang berkepentingan terutama regulator/BAPEPAM. 


\section{Hipotesis Kedua}

\section{$\mathrm{HO}_{2}$ : Tidak ada pengaruh leverage pada audit delay}

Pada tabel leverage yang dihitung dengan rumus total utang dibagi dengan total modal memiliki koefisien regresi negatif sebesar -8.354 dengan tingkat signifikansi sebesar 0.653 yang lebih besar dari 0.05. Berdasarkan hal tersebut dapat disimpulkan bahwa variabel leverage tidak berpengaruh signifikan dan negatif terhadap audit delay.

Hasil dari penelitian ini sejalan dengan hasil penelitian yang dilakukan Utari Hilmi dan Syaiful Ali (2008). Dimana hasil penelitian yang dilakukan menyatakan bahwa leverage perusahaan tidak dapat berpengaruh secara signifikan terhadap Audit Delay. Namun hal ini bertentangan dengan penelitian yang dilakukan oleh Silvia Angruningrum dan Made Gede Wirakusuma (2013) dan Debby Delbhia (2014) yang membuktikan bahwa leverage dapat berpengaruh secara signifikan terhadap Audit Delay. Perbedaan ini dikarenakan pemilihan sampel penelitian yang berbeda, periode tahun yang berbeda dan analisis yang berbeda.

Dari hasil penelitian tersebut dapat disimpulkan bahwa perusahaan yang memiliki tingkat leverage rendah tidak mempengaruhi lamanya penyelesaian dari audit independen.

\section{Hipotesis Ketiga}

\section{$\mathrm{H}_{3}$ : Tidak ada pengaruh kompleksitas operasional pada audit delay}

Pada tabel kompleksitas operasi memiliki koefisien negatif sebesar -1.029 dengan tingkat signifikansi sebesar 0.50 yang lebih besar dari 0.05. Berdasarkan hal tersebut dapat disimpulkan bahwa variabel kompleksitas operasi tidak berpengaruh signifikan dan negative terhadap audit delay. Hasil dari penelitian ini sejalan dengan hasil penelitian yang dilakukan oleh Silvia Angruningrum dan Made Gede Wirakusuma (2013). Dimana hasil penelitian menyatakan bahwa kompleksitas operasi perusahaan yang dilihat dari jumlah keberadaan anak perusahaan klien tidak berpengaruh terhadap Audit Delay. Namun hal ini bertentangan dengan penelitian yang dilakukan oleh Oviek Dewi Saputri (2012) karena hasil penelitiannya membuktikan bahwa kompleksitas operasi perusahaan yang dilihat dari diversifikasi bisnis operasi klien dan jumlah anak perusahaan klien dapat berpengaruh terhadap Audit Delay

\section{Hipotesis Keempat}

\section{$\mathrm{HO}_{4}$ : Tidak ada pengaruh reputasi KAP pada audit delay.}

Pada tabel reputasi KAP yang dilihat dari berafiliasi atau tidak dengan Kantor Akuntan Publik Big Four memiliki koefisien regresi positif 1.749 dengan tingkat signifikansi 0.344 yang lebih besar dari 0.05 . Berdasarkan hal tersebut dapat disimpulkan bahwa reputasi KAP tidak berpengaruh signifikan dan positif terhadap .

Hasil dari penelitian ini sejalan dengan hasil penelitian yang dilakukan Novi Wiji Lestari (2012) dan Silvia Angruningrum dan Made Gede Wirakusuma (2013), dan Silvia Angruningrum dan Made Gede Wirakusuma (2013) menyatakan bahwa reputasi KAP yang dilihat dari perusahaan yang diaudit oleh KAP lokal yang berafiliasi dengan KAP Big Four 
atau oleh KAP lokal yang tidak berafiliasi dengan KAP Big Four tidak dapat berpengaruh terhadap audit delay. Namun hal ini bertentangan dengan penelitian yang dilakukan oleh Utari Hilmi dan Syaiful Ali (2008). Karena Utari Hilmi dan Syaiful Ali (2008) yang dilihat perusahaan yang diaudit oleh KAP lokal yang berafiliasi dengan KAP Big Four atau oleh KAP lokal yang tidak berafiliasi dengan KAP Big Four dapat berpengaruh terhadap audit delay.

\section{Hipotesis Kelima}

\section{H05 : Tidak ada pengaruh komite audit pada audit delay}

Pada tabel komite audit memiliki koefisien regresi positif 1.097 dengan tingkat signifikansi 0.840 yang lebih dari 0.05 . Berdasarkan hal tersebut dapat disimpulkan bahwa variabel komite audit tidak berpengaruh sigifikan dan positif terhadap audit delay.

Hasil dari penelitian ini sejalan dengan hasil penelitian yang dilakukan Silvia Angruningrum dan Made Gede Wirakusuma (2013). Dimana hasil penelitian ini menyatakan bahwa komite audit perusahaan yang dilihat dari perbandingan antara jumlah total anggota komite audit dengan jumlah anggota yang memiliki latarbelakang akuntansi dan keuangan tidak berpengaruh terhadap audit delay. Namun hal ini tidak selaras atau sejalan dengan penelitian yang dilakukan oleh Rahayu Mumpuni SA (2011) yang menyatakan bahwa komite audit perusahaan yang dilihat berdasarkan jumlah anggotanya berpengaruh terhadap audit delay. Perbedaan ini dikarenakan tolak ukur yang berbeda.

Dari hal tersebut dapat dinyatakan bahwa jumlah anggota komite audit perusahaan tidak mempengaruhi lamanya dalam penyampaian laporan keuangan auditan. Karena pada umumnya sampel dari pengujian ini telah memenuhi ketentuan.

\section{Hipotesis Keenam}

\section{Ha6 : Ada pengaruh profitabilitas, leverage, kompleksitas operasi, reputasi KAP dan komite audit pada audit delay}

Pada tabel menunjukkan hasil secara simultan bahwa profitabilitas, leverage, kompleksitas operasi, reputasi KAP dan komite audit berpengaruh signifikan dan positif terhadap audit delay. Berdasarkan tabel tersebut Chi-square sebesar 4.663 dengan tingkat signifikansi 0.026 kurang dari 0.05 maka dapat disimpulkan bahwa profitabilitas, leverage, kompleksitas operasi, reputasi kap dan komite audit secara simultan dan bersama-sama berpengaruh terhadap audit delay.

Hasil dari penelitian ini selaras secara keseluruhan dengan hasil penelitian yang dilakukan Silvia Angruningrum dan Made Gede Wirakusuma (2013) dan selaras secara sebagian dengan hasil penelitian yang dilakukan Utari Hilmi dan Syaiful Ali (2008). Namun hal ini tidak selaras secara keseluruhan dengan penelitian yang dilakukan Debby Delbhia (2014). 


\section{KESIMPULAN DAN SARAN}

Berdasarkan hasil analisis dan pembahasan, maka dapat disimpulkan dan saran sebagai berikut :

\section{Kesimpulan :}

- Profitabilitas berpengaruh signifikan dan positif terhadap audit delay. Hasil pengujian menunjukkan variabel profitabilitas yang dilihat berdasarkan nilai rasio return on assets (ROA) dapat berpengaruh signifikan dan positif terhadap audit delay.

- Leverage tidak berpengaruh terhadap audit delay. Hasil pengujian menunjukkan variabel leverage yang dilihat berdasarkan nilai dept of equity (DER) tidak dapat berpengaruh signifikan dan negative terhadap audit delay.

- Kompleksitas operasi berpengaruh terhadap audit delay. Hasil pengujian menunjukkan variabel kompleksitas operasi yang dilihat berdasarkan keberadaan anak perusahaan tidak dapat berpengaruh signifikan dan negative terhadap audit delay.

- Reputasi KAP tidak berpengaruh terhadap audit delay. Hasil pengujian menunjukkan variabel reputasi KAP yang dilihat dari berafiliasi atau tidak dengan Kantor Akuntan Publik Big Four tidak dapat berpengaruh signifikan dan positif terhadap audit delay.

- Komite audit tidak berpengaruh terhadap audit delay. Hasil pengujian variabel komite audit yang dilihat dari perbandingan total jumlah anggota audit dengan jumlah anggota yang memiliki latarbelakang akuntansi dan keuangan tidak dapat berpengaruh terhadap audit delay.

- Profitabilitas, leverage, kompleksitas operasi, reputasi kap dan komite audit secara simultan (bersama-sama) berpengaruh terh

\section{Saran :}

- Penelitian mengenai audit delay pada penelitian selanjutnya diharapkan mampu memberikan hasil penelitian yang lebih berkualitas, dengan mempertimbangkan saran berikut ini:

- Penelitian selanjutnya diharapkan menggunakan populasi dari sektor perusahaan yang berbeda atau seluruh perusahaan yang terdaftar di Bursa Efek Indonesia.

- Penelitian selanjutnya diharapkan menggunakan time series yang lebih lama dibandingkan penelitian ini yang hanya menggunakan time series selama tiga tahun.

- Melakukan penelitian dengan objek yang berbeda misalkan menggunakan jenis usaha sektor perbankan maupun agraria untuk memeproleh konsistensi hasil penelitian. Dan menggunakan lebih banyak variabel lain seperti internal audit, ukuran perusahaan dan lainnya yang dapat digunakan untuk menguji Audit Delay. 
- Penelitian lain yang serupa juga dapat dilakukan untuk mengkonfirmasi hasil penelitian ini dengan menggunakan pendekatan uji yang berbeda atau menambah variabel lain yang dirasa dapat mempengaruhi Audit Delay.

\section{DAFTAR PUSTAKA}

Ghozali, Imam. 2013. Aplikasi Analisis Multivariate dengan Program SPSS. Semarang : BP Universitas Diponegoro.

Hanafi, Mamduh M. dan Halim, Abdul. 2012. Analisis Laporan Keuangan. Yogyakarta : UPP Sekolah Tinggi Ilmu Manajemen YKPN.

Harahap, Sofyan Syafri. 2016. Analisis Kritis atas Laporan Keuangan. Jakarta : PT Raja Grafindo Persada.

Ikatan Akuntansi Indonesia (IAI). 2009. Standar Akuntansi Keuangan. Jakarta : Salemba Empat.

Kieso, Donald E., Weygandt, Jerry J., dan Warfield, Terry D. 2007. Akuntansi Intermediate Jilid 1. Edisi Keduabelas. Jakarta : Erlangga.

Mulyadi. 2014. Auditing Buku 1. Edisi Ke-6. Jakarta : Salemba Empat.

Sujarweni, V. Wiratna. 2015. SPSS Untuk Penelitian. Yogyakarta : Pustaka Baru Press.

Angruningrum, Silvia dan Wirakusuma, Made Gede. 2013. "Pengaruh Profitabilitas, Leverage, Kompleksitas Operasi, Reputasi KAP Dan Komite Audit Pada Audit Delay” E-Jurnal Akuntansi Universitas Udayana No. 5.2 Tahun 2013 : 251-270.

Hilmi, Utari dan Ali, Syaiful. 2008. “Analisis Faktor-Faktor yang Mempengaruhi Ketepatan Waktu Penyampaian Laporan Keuangan (Study Empiris Pada Perusahaan Yang Terdaftar di BEJ".

Delbhia, Debby. 2014. "Analisis Faktor- Faktor Yang Mempengaruhi Audit Delay : Studi Empiris Pada Perusahaan Manufaktur Yang Terdaftar Di Bursa Efek Indonesia Pada Tahun 2007-2012”.

Febrianty. 2011. "Faktor-Faktor Yang Berpengaruh Terhadap Audit Delay Perusahaan Sektor Perdagangan Yang Terdaftar Di Bei Periode 2007-2009". Jurnal Ekonomi dan Informasi Akuntansi, September 2011 : 294-320, Vol. 1, No.3.

Mumpuni SA., Rahayu. 2011. Analisis Faktor-faktor yang Mempengaruhi Audit delay Pada Perusahaan Nonkeuangan Di Bursa Efek Indonesia Tahun 2006-2008. Skripsi: Universitas Diponogoro

Surat Edaran Keputusan Ketua Badan Pengawas Pasar Modal (BEPEPAM) Nomor Kep36/PM/2003 Nomor X.K.2. 
Surat Edaran Peraturan Pemerintah Republik Indonesia No. 45 Tahun 1995 Tentang Penyelenggaraan Kegiatan Di Bidang Pasar Modal

Surat Edaran Keputusan BAPEPAM \& LK NOMOR : KEP-36/PM/2003.

Saputri, Oviek Dewi. 2012. Analisis Faktor-Faktor Yang Mempengaruhi Audit delay (Studi Empiris Pada Perusahaan-Perusahaan Yang Terdaftar Di Bursa Efek Indonesia). Skripsi Universitas Diponegoro.

Wiji, Novi Lestari. 2012. Faktor- faktor yang mempengaruhi Audit Delay. Skripsi Fakultas Ekonomi Akuntansi Unversitas Satya Negara Indonesia

$\underline{\text { www.idx.go.id }}$

WWW.sampoerna.com 